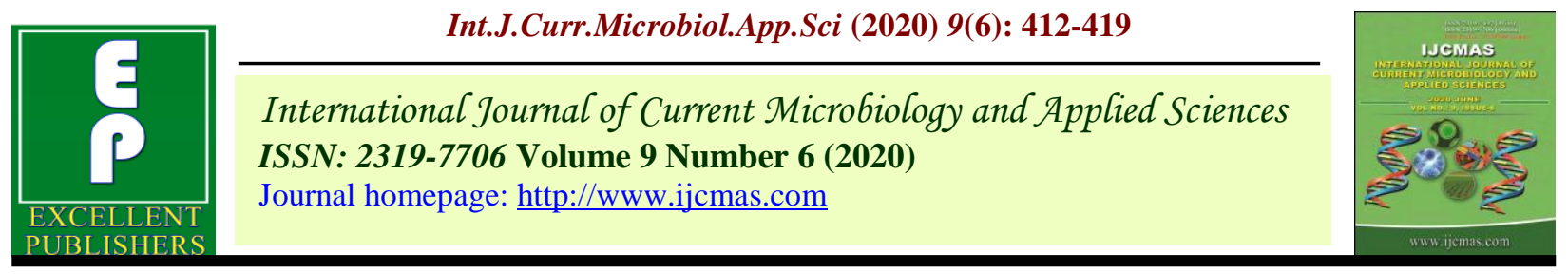

Original Research Article

https://doi.org/10.20546/ijcmas.2020.906.054

\title{
Evaluation of Physico-Chemical Properties of Multi-Flour Based Noodles
}

\author{
Kapil Kumar*, Suresh Chandra, Samsher and Ratnesh Kumar \\ Department of Agricultural Engineering and Food Technology, Sardar Vallabhbhai Patel \\ University of Agriculture and Technology, Meerut-250110 (U.P.), India \\ *Corresponding author
}

Ke y w o r d s
$\begin{aligned} & \text { Noodles, Multi- } \\ & \text { flour, Physico- } \\ & \text { chemical properties, } \\ & \text { Statistical software }\end{aligned}$
Article Info
$\begin{aligned} & \text { Accepted: } \\ & 15 \text { May } 2020 \\ & \text { Available Online: } \\ & \text { 10 June } 2020\end{aligned}$

Keywords

Noodles, Multi-

flour, Physico-

chemical properties,

\section{A B S T R A C T}

This study was performed to investigate the physico- chemical characteristics of multi flour noodles were prepared by blending wheat flour with kidney bean flour, cowpea flour, turnip flour and cauliflower flour in six different treatments. The physico-chemical properties moisture, ash, protein, fat, crude fibre, iron, calcium, sodium and potassium of multi flours noodles were determined using standard procedures just after preparation. All the data of study were also statistically analyzed by using factorial Randomized Block Design (RBD) with the help of OPSTAT software. The present study revealed that the noodles made from composite flour $\mathrm{W}_{90}$ was observed rich in protein and fat content properties. All types of multi flours noodles were made from multi flour are acceptable.

\section{Introduction}

Noodles are a vital part within the diet of many countries. Many types of noodles are produced with different composition, methods of preparation and presentation depending on regional preferences (Edwards et al., 1996). Noodles are one in every of the convenient food prepared and are considered to symbolize long life and good luck in Asian culture (Sowbhagya and Ali, 1994). Wheat based noodles are nutritious, store well and are easy to prepare. Indofood is the largest instant noodles manufacturer in the world, with installed capacities of approximately 13 billion packs per annum (Fabiosa, 2006). But the scientists have found that the fruits and vegetables contain higher level of cellulose than cereals (Wahlqvist, 1993).

Besides having good amount of dietary fibre, vegetables and fruits are also considered to be chemical power houses that produce dozens of unique, complex and biologically active organic compounds which are known to effect significantly the quality and duration of life (Fraser, 1994). Noodles are one of the main staple foods consumed in East and Southeast 
Asian countries, representing up to 40 percent of total flour consumption. Though some Asian- style noodles are wheat based, many other are made from ingredients such as rice flour, potato flour, buck wheat flour, corn flour and bean, yam or soybean flour.

The world instant noodle market is projected to reach 158.7 billion packs by the year 2010(Anon, 2005). This is because instant noodles are easy to cook, low in cost and have a comparatively long shelf-life. Apple Pomace is low in cost.

Therefore, fortification of wheat flour with apple pomace can reduce the production cost and thus providing a product with a higher nutritional quality. Instant noodles are made up of from wheat flour (primarily) and/or rice flour and/or other flours by the utilization of a pre-gelatinization process and dehydration.

They are generally fried to decrease their cooking time. Instant noodles are often packaged with a seasoning sachet for flavor or during a cup with powdered soup base sprinkled over it (Gulia et al., 2014).

There is a rapid development and processing industries in recent decades with a series of interlinked activities such as production of noodles, pasta and the demand of lead free/multigrain noodles is increasing rapidly both in domestic and in international market with major protein of it being used for preparation of convenience food. Noodles of different kinds together with boiled rice have been the staple food of almost all Asian countries.

Since noodles are always in the form of long strands, they are symbolic of longevity. There are different ways of consuming them as well as different recipes available at different countries. Most of these noodles are consumed hot as in soup, like a pasta plate or stir-fried with meat, shrimps and with vegetables. Others are consumed cold like in the case of some soba dishes in Japan. Also there are numerous types that depend on the raw materials, product shapes, processing methods and the way of preparation and serving.

However, they have also undergone changes driven by technical innovations and consumer demands. Economics plays also an important role since food based on noodles can be easily afforded by people in the low-income bracket. Moreover, a dish containing oriental noodles can be a complete and nutritious meal.

Wheat flour approximately consists of $72 \%$ carbohydrates, 8 to $13 \%$ protein, 12 to $13 \%$ moisture, $2.5 \%$ sugar and $1.5 \%$ fat, $1.0 \%$ soluble protein and $0.5 \%$ minerals salts (Oberoi et al., 2007). Wheat flour is main ingredients used in the manufacturing of noodles and characteristics of wheat used for milling are very important. Soft wheat is used in cakes, pastries, cookies, crackers and oriental noodles where as hard wheat is used in breads. Cowpea is loaded with various types of nutrients. It is rich in fiber, protein, iron, potassium, low in fat and calories.

The kidney bean is an important food crop, and a major source of protein throughout the world. It is used in a variety of traditional dishes, kidney beans are usually eaten well cooked. Cauliflower is an excellent source of vitamin $\mathrm{C}$, vitamin $\mathrm{K}$, folate, pantothenic acid, and vitamin B6. It is a very good source for body.

Turnip also contain B vitamins (riboflavin, folates, pyridoxine pantothenic acid, and thiamin), calcium, copper, manganese, and iron, as well as phytonutrients like quercetin, myricetin, kaempferol, and hydroxycinnamic acid, which help lower your risk of oxidative stress (Kumar et al., 2017). 


\section{Materials and Methods}

Raw materials viz., wheat flour, kidney bean, cowpea, turnip, cauliflower etc. were procured from the local market of Meerut (U.P) for the study in year.

\section{Preparation of wheat flour}

Wheat flour was procured from the local market of Modipuram, Meerut and mixed with other flour for preparation of composite flour.

\section{Preparation of kidney bean flour}

Kidney bean was procured from local market and after completely cleaning all the impurities and removed the damaged and infested grain manually. The cleaned kidney bean was soaked overnight to destroy the antinutritional factor by soaking (Chandra et al., 2010).

Soaked kidney bean was dried in tray drier upto very low moisture content and grind by domestic Atta chakki (BGS-96 Biogen Scientific) into two-three pass. Kidney bean flour was also sieved (BS-60).

\section{Preparation of cowpea flour}

Cowpea was procured from local market and after completely cleaning all the impurities and removed the damaged and infested grain manually. Soaked cowpea was dried in tray drier upto very low moisture content and grind by domestic Atta chakki(BGS-96 Biogen Scientific) into two-three pass. Cowpea flour was also sieved (BS-60).

\section{Preparation of turnip and cauliflower flour}

Turnip and cauliflower was procured from local market and after completely washing \& trimming all the impurities and removed the damaged and peeled/ chopped manually. Blanched turnip was dried in tray drier upto very low moisture content and grind by grinder into two-three pass. Turnip flour was also sieved (BS-60).

\section{Preparation of composite flour}

Composite flour was prepared by blending wheat flour with kidney bean flour, cowpea flour, turnip flour, cauliflower flour in ratio of 100:0:0:0:0 $\left(\mathrm{W}_{100}\right), 90: 2.5: 2.5: 2.5: 2.5 \quad\left(\mathrm{~W}_{90}\right)$, 80:5:5:5:5 $\left(\mathrm{W}_{80}\right), \quad$ 70:7.5:7.5:7.5:7.5 $\left(\mathrm{W}_{70}\right)$, 60:10:10:10:10 $\left(\mathrm{W}_{60}\right)$ and 50:12.5:12.5:12. $5: 12.5\left(\mathrm{~W}_{50}\right)$.

\section{Development of noodles from multi flour}

Noodles were prepared from mixing different type of flours called multi flour noodle and the process flow diagram is given in Fig. 1.

\section{Proximate analysis}

The Physico chemical properties of multi flours noodles were analyzed i.e., Moisture by oven drying method, Ash by dry ashing, Protein by Kjeldahl's method, Fat by soxhlet method, Crude Fibre by gravimetric methods (AOAC,1995), Iron, Calcium, Sodium and Potassium were determined as per standard procedure of (AOAC, 2012). The chemical used in this study were analytical grade. All analyses were performed in triplicate.

\section{Results and Discussion}

The present investigation was undertaken to develop nutritious noodles from the composite flours. The wheat flour was blended with kidney bean flour, cowpea flour, turnip flour and cauliflower flour in various combinations to prepare composite flour noodles. Physico-chemical properties of noodles were evaluated just after preparation. 


\section{Moisture}

The moisture content of multi flours i.e. $\mathrm{W}_{100}(8.16 \%), \quad \mathrm{W}_{90}(8.12 \%), \mathrm{W}_{80}(8.05 \%)$, $\mathrm{W}_{70}(8.00 \%) \mathrm{W}_{60}(7.90 \%)$ and $\mathrm{W}_{50}(7.85 \%)$ were also determined. From Table 1, it is clear that the moisture content were gradually decreased due to increase in the incorporation of different flours. All the noodles, from Table 1 indicated that the control noodles absorbed higher moisture from the ambient as compared to other samples because of wheat flour had higher hygroscopicity property than others flours.

The study revealed that moisture content of composite flours decreased with decrease in proportions of wheat flour from $100 \%$ to $50 \%$. Similar trends were reported by (Kaushal et al., 2012). They used the blends of taro, rice and pigeon pea flour which resulted in reduction of moisture content of composite flours.

\section{Ash}

The ash content of noodles increased with increasing proportions of different flours with wheat flour. Ash content increased gradually in the range for control noodles $(1.42 \%), \mathrm{W}_{90}$ $(1.55 \%), \mathrm{W}_{80}(1.77 \%), \mathrm{W}_{70}(1.91 \%), \mathrm{W}_{60}$ $(1.98 \%)$ and $\mathrm{W}_{50}$ noodles $(2.10 \%)$. Ash is non-organic compound containing mineral content of food and nutritionally it aids in the metabolism of the other organic compounds such fat and carbohydrate (McWilliam, 1978).

The multi flour noodles $\left(\mathrm{W}_{50}\right)$ had highest ash content. Nutritionally, this means that when used as Multi flours, it will improve the ash content of the products. Similar trends were found by (Agu et al., 2007). They reported that ash content of biscuit made from wheat and African bread fruit (Trecula africana) with different proportion ranged from 0.99 to $1.33 \%$.
The ash content increased with increase in the bread fruit proportion. Nutritionally this means that when used as composite flour it will improve the ash content of the product.

\section{Protein}

Protein content for freshly prepared noodles among all incorporation of flours was observed for control noodles $(12.70 \%), \mathrm{W}_{90}$ $(12.60 \%), \mathrm{W}_{80}(12.45 \%), \mathrm{W}_{70}(12.30 \%), \mathrm{W}_{60}$ $(12.05 \%)$ and $\mathrm{W}_{50}(11.90 \%)$. The protein content of noodles was decreased with increase in the incorporation of kidney bean, cowpea, turnip and cauliflower flour with wheat flour. The proportion of turnip flour was adversely affecting the protein content of noodle due to lack of protein content as compared to other food commodity. According to (Chan et al., 2013), defatted kenaf seed meal (DKSM) was found to contain high content of proteins (26.19\%). Thus, the results suggest that the steaming of noodles (Temp $>45^{\circ} \mathrm{C}$ ) denatured the protein during preparation.

\section{Fat}

The fat of fresh noodles was estimated for control noodles $(5.43 \%), \mathrm{W}_{90}(5.36 \%), \mathrm{W}_{80}$ $(5.28 \%), \mathrm{W}_{70}(5.20 \%), \mathrm{W}_{60}(5.12 \%)$ and $\mathrm{W}_{50}$ noodles $(4.94 \%)$. The fat content of composite flour noodles incorporated kidney bean, cowpea, turnip and cauliflower flour with wheat flour was observed lower as compared to control noodles. The lower fat in composite flour noodles might be due to lower fat content in turnip and cauliflower flour as compared to wheat flour, kidney bean flour and cowpea flour. Wheat flour has been known to have approximately about 2 to $3 \%$ of fat content (Niihara et al., 1996). Moreover, fat content was decreased with formation of an amylose-lipid complex resulting from heat treatment in noodle preparation. 


\section{Crude fibre}

The crude fiber of fresh noodles was noticed in control noodles $(0.89 \%), \mathrm{W}_{90}(1.58 \%), \mathrm{W}_{80}$ $(1.81 \%), \mathrm{W}_{70}(2.10 \%), \mathrm{W}_{60}(2.21 \%)$ and $\mathrm{W}_{50}$ noodles $(2.30 \%)$. The crude fibre of noodles increased with increasing the incorporation of kidney bean, cowpea, turnip and cauliflower flour with wheat flour.

The higher fibre in composite flour noodles might be due to high fibre content in kidney bean and cowpea flour as compared to wheat flour, turnip and cauliflower flour. Similar trends were found by (Anu and Kawatra2007) and Stojceska et al., 2008) in cauliflower supplemented cereal based ready-to-eat expanded snacks.

\section{Iron}

The iron for fresh noodles was found 4.63$3.90 \mathrm{mg} / 100 \mathrm{gm}$ among all the noodles samples. Highest iron was evaluated for $\mathrm{W}_{100}$ noodles $(4.63 \mathrm{mg} / 100 \mathrm{gm})$ followed by $\mathrm{W}_{90}$ $(4.55 \mathrm{mg} / 100 \mathrm{gm}), \mathrm{W}_{80}(4.40 \mathrm{mg} / 100 \mathrm{gm}), \mathrm{W}_{70}$ $(4.30 \mathrm{mg} / 100 \mathrm{gm}), \mathrm{W}_{60}(4.00 \mathrm{mg} / 100 \mathrm{gm})$ while lowest for $\mathrm{W}_{50}$ noodles $(3.90 \mathrm{mg} / 100 \mathrm{gm})$.

The iron of noodles decreased with increasing the incorporation of kidney bean, cowpea, turnip and cauliflower flour with wheat flour. The lower iron in composite flour noodles might be due to low iron content in turnip and cauliflower as compared to wheat flour, kidney bean and cowpea flour.

\section{Calcium}

The calcium for fresh noodles was observed $31.21-47.17 \mathrm{mg} / 100 \mathrm{gm}$ among all the noodles samples. Highest calcium was evaluated for $\mathrm{W}_{50}$ noodles $(47.17 \mathrm{mg} / 100 \mathrm{gm})$ followed by $\mathrm{W}_{60} \quad(44.26 \quad \mathrm{mg} / 100 \mathrm{gm}), \quad \mathrm{W}_{70} \quad(40.11$ $\mathrm{mg} / 100 \mathrm{gm}), \quad \mathrm{W}_{80}(38.02 \mathrm{mg} / 100 \mathrm{gm}), \quad \mathrm{W}_{90}$ (33.12 mg/100gm) while lowest for control noodles $(31.21 \mathrm{mg} / 100 \mathrm{gm})$. The result of study revealed that the calcium of noodles increased with increasing the incorporation of kidney bean, cowpea, turnip and cauliflower flour with wheat flour. The higher calcium in composite flour noodles might be due to high calcium content in turnip flour and cowpea as compared to wheat flour, kidney bean flour and cauliflower flour.

\section{Sodium}

The sodium in fresh noodles was calculated $4.25-11.87 \mathrm{mg} / 100 \mathrm{gm}$ among all the noodles samples. Highest sodium was observed for $\mathrm{W}_{50}$ noodles $(11.87 \mathrm{mg} / 100 \mathrm{gm})$ followed by $\mathrm{W}_{60}(10.91 \mathrm{mg} / 100 \mathrm{gm}), \mathrm{W}_{70}(9.10 \mathrm{mg} / 100 \mathrm{gm})$, $\mathrm{W}_{80}(7.11 \mathrm{mg} / 100 \mathrm{gm}), \mathrm{W}_{90}(5.81 \mathrm{mg} / 100 \mathrm{gm})$ while lowest for control noodles $(4.25 \mathrm{mg} / 100 \mathrm{gm})$. The sodium of noodles increased with increasing the incorporation of kidney bean, cowpea, cauliflower and turnip flour with wheat flour.

The higher sodium in composite flour noodles might be due to high sodium content in turnip flour and cauliflower as compared to wheat flour, kidney bean flour and cowpea flour.

\section{Potassium}

The potassium for fresh noodles was recorded $90.32-199.18 \mathrm{mg} / 100 \mathrm{gm}$ among all the noodles samples. Highest potassium was evaluated for $\mathrm{W}_{50}$ noodles $(199.18 \mathrm{mg} / 100 \mathrm{gm})$ followed by $\mathrm{W}_{60} \quad(168.24 \mathrm{mg} / 100 \mathrm{gm}), \mathrm{W}_{70}$ $(145.46 \mathrm{mg} / 100 \mathrm{gm}), \mathrm{W}_{80}(120.36 \mathrm{mg} / 100 \mathrm{gm}), \mathrm{W}$ $9098.18 \mathrm{mg} / 100 \mathrm{gm})$ while lowest for control noodles $(90.32 \mathrm{mg} / 100 \mathrm{gm})$. The potassium of noodles increased with increasing the incorporation of kidney bean, cowpea, turnip and cauliflower flour with wheat flour. The higher potassium in multi flour noodles might be due to high potassium content in cowpea flour as compared to wheat flour, kidney bean flour, turnip and cauliflower flour. 
Table.1 Physico-chemical properties of multi flour noodles

\begin{tabular}{|l|c|c|c|c|c|c|}
\hline \multicolumn{1}{|c|}{$\begin{array}{c}\text { Physio- Chemical } \\
\text { Properties }\end{array}$} & $\mathbf{W}_{\mathbf{1 0 0}}$ & $\mathbf{W}_{\mathbf{9 0}}$ & $\mathbf{W}_{\mathbf{8 0}}$ & $\mathbf{W}_{\mathbf{7 0}}$ & $\mathbf{W}_{\mathbf{6 0}}$ & $\mathbf{W}_{\mathbf{5 0}}$ \\
\hline Moisture, (\%) & 8.16 & 8.12 & 8.05 & 8.00 & 7.90 & 7.85 \\
& \pm 0.40 & \pm 0.48 & \pm 0.24 & \pm 0.40 & \pm 0.55 & \pm 0.31 \\
\hline Ash, (\%) & 1.42 & 1.55 & 1.77 & 1.91 & 1.98 & 2.10 \\
& \pm 0.07 & \pm 0.09 & \pm 0.05 & \pm 0.09 & \pm 0.13 & \pm 0.08 \\
\hline Protein, (\%) & 12.70 & 12.60 & 12.45 & 12.30 & 12.05 & 11.90 \\
& \pm 0.63 & \pm 0.75 & \pm 0.37 & \pm 0.61 & \pm 0.84 & \pm 0.47 \\
\hline Fat, (\%) & 5.43 & 5.36 & 5.28 & 5.20 & 5.12 & 4.94 \\
& \pm 0.27 & \pm 0.32 & \pm 0.15 & \pm 0.26 & \pm 0.35 & \pm 0.19 \\
\hline Crude Fibre, (\%) & 0.89 & 1.58 & 1.81 & 2.10 & 2.21 & 2.30 \\
& \pm 0.04 & \pm 0.09 & \pm 0.05 & \pm 0.10 & \pm 0.15 & \pm 0.09 \\
\hline Iron (mg/100g) & 4.63 & 4.55 & 4.40 & 4.30 & 4.00 & 3.90 \\
& \pm 0.23 & \pm 0.27 & \pm 0.13 & \pm 0.21 & \pm 0.28 & \pm 0.15 \\
\hline Calcium, (mg/100g) & 31.21 & 33.12 & 38.02 & 40.11 & 44.26 & 47.17 \\
& \pm 1.56 & \pm 1.98 & \pm 1.14 & \pm 2.00 & \pm 3.09 & \pm 1.88 \\
\hline Sodium, (mg/100g) & 4.25 & 5.81 & 7.11 & 9.10 & 10.91 & 11.87 \\
& \pm 0.21 & \pm 0.34 & \pm 0.21 & \pm 0.45 & \pm 0.76 & \pm 0.47 \\
\hline Potassium, (mg/100g) & 90.32 & 98.18 & 120.36 & 145.46 & 168.24 & 199.18 \\
& \pm 4.51 & \pm 5.89 & \pm 3.61 & \pm 7.27 & \pm 11.77 & \pm 7.96 \\
\hline
\end{tabular}
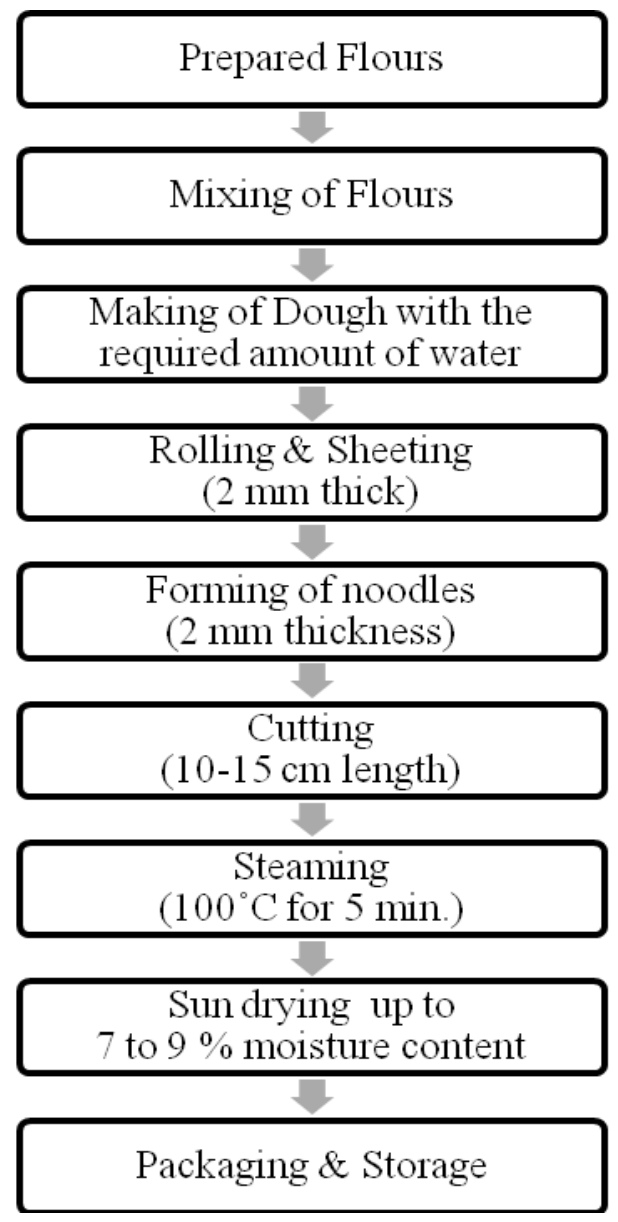

Fig.1 Process flow chart for development of multi flour noodles 
Nowadays, noodles are staple food in Asian countries. The demand of noodles are increasing day by day due to easy cooking, available in market and can be loaded with more nutritious compound during processing. The malnutrition is drastic problem in children in tiny stage. Thus, it is necessary to make the noodles with other food products fortified with adding the essential basic nutrient in powder or liquid form in noodles. The present study revealed that the various types of food commodity were used to prepare the noodles. As per literature the each ingredient was rich and important as per nutrient content. This study was found also in the favour of farmer, to increase the production and consumption of turnip \& cauliflower in human diet. After drying it could be used in different recipe of noodles and pasta making. In this study suggested that the dried and powdered form of the food commodities can be increased the nutritional content of the noodles.

\section{References}

AOAC. (1995). Official Methods of Analysis, $16^{\text {th }}$ ed. Association of Official Analytical Chemists. Arlington, VA.

Agu, H.O., Ayo, J.A., Paul, A.M. and Folorunsho, F. (2007). Quality characteristics of biscuits made from wheat and African breadfruit (Treculia Africana). Nigerian Food Journal 25(2):19-27.

Anon. (2005). Approved methods of American Association of cereal Chemists, 8th Ed. AACC, The Association: St. Paul, MN.

Anu, S.S. and Kawatra, A. (2007). Use of pearl millet and green gram flours in biscuit and their sensory and nutritional quality. Journal Food Sci. Technol. 44(5):536-538.

AOAC. (2012).Association of Analytical Communities. 999.11.
Chan, K. W., Khong, N.M.H., Iqbal, S., Mansor, S.M., Ismail, M. (2013). Defatted kenaf seed meal (DKSM): prospective edible flour for agricultural wastes with high antioxidant activity, LWT-food science and technology, doi: 10.1016/j.lwt.2013.01.003.

Chandra, S., Kumari, D., Samsher and Goyal, S. K. (2010). Anti-nutritional factors in food and their effect. Beverage and food world, 37 (2): 61-63.

Edwards, N.M., Seanlan, M.G., Kruger, J.E. and Dexter, J.E. (1996). Oriental noodles dough rheology: Relationship to water absorption, formulation and work input during dough sheeting. Cereal Chem. 73:708-711.

Fabiosa, J.F. (2006). Westernization of the Asian diet-the case of rising wheat consumption in Indonesia. Working paper 06-WP-422, Centre for Agricultural and Rural Development, Iowa State University, Ames, Iowa.

Fraser, G. E. (1994). Diet and coronary heart diseases: Beyond dietary fats and low density lipoprotein cholesterol. American Journal of Clinical Nutrition, 59: 1178-1235.

Gulia, N., Dhaka V. and Khatkar, B.S. (2014). Instant noodles: Processing, quality, and nutritional aspects. Crit Rev Food Sc Nutr; 54(10): 1386-99.

Kaushal, P., Kumar, V. and Sharma, H.K. (2012). Comparative study of physicochemical, functional, anti-nutritional and pasting properties of taro (Colocasia esculenta), rice (Oryza sativa), pegion pea (Cajanus cajan) flour and their blends. LWT-Food Sci. Technol. 48:59-68.

Kumar, K., Chandra, S., Samsher, Chauhan, N., Singh, J. and Kumar, M. (2017).Functional properties of food commodities (wheat, kidney bean, cowpea, turnip, cauliflower) flours. International Journal of Chemical 
Studies 5(6): 1199-1202, 37 (2): 61-63.

McWilliam, M. (1978). Food Fundamental. $3^{\text {rd }}$ edition. California State University, Los Angeles. P. 27-29.

Niihara, R., Yonezawa, D. and Matsuo, R. R. (1996). Role of lipids on pasta and noodle quality. In J. E. Kruger, R. B. Matsuo and J. W. Dick (Eds), Pasta and Noodle Technology (pp.275-300), St Paul. MN, USA: American Association of Cereal Chemists, Inc.

Oberoi DPS, Sogi DS, Gill BS (2007). Noodle Processing Technology. Bev.
Food World 34(10): 68-70, 72.

Sowbhagya, C.M. and Ali, S.Z. (1994). A process for making the noodles from maize. Indian Patent. 1: 83, 077.

Stojceska V., Ainsworth P., Plunkett A. and Ibanoğlu S. (2008). The recycling of brewer's processing by-product into ready-to-eat snacks using extrusion technology. Journal of Cereal Science, 47: 469-479.

Wahlquvist, M. L. (1993). Nutritional factors in carcinogenesis. Journal of Clinical Nutrition, 2: 141-148.

\section{How to cite this article:}

Kapil Kumar, Suresh Chandra, Samsher and Ratnesh Kumar. 2020. Evaluation of PhysicoChemical Properties of Multi-Flour Based Noodles. Int.J.Curr.Microbiol.App.Sci. 9(06): 412419.doi: https://doi.org/10.20546/ijcmas.2020.906.054 